LEAD ARTICLE

\title{
GEO-BIO INTERACTIONS: IMPLICATIONS ON PLANT AND HUMAN HEALTH
}

\author{
C.B. Dissanayake \\ Institute of Fundamental Studies, Hantana Road, Kandy, Sri Lanka
}

\begin{abstract}
Rocks are the fundamental building blocks of the earth. Chemical weathering of rocks of different chemical compositions yields soils with their characteristic chemistry reflecting in part the original composition of the rocks. These soils may therefore, have major and trace elements in varying quantities and these concentrations then influence the nature of plants growing on them and the composition of the groundwater. In all geochemical cycles therefore, the multitude of interactions between the geosphere hydrosphere and biosphere yield fascinating impacts on plant growth and human health. The general health of a population living on a particular geological environment therefore is markedly influenced by the chemistry of that geological environment.
\end{abstract}

Key words: geological environment, trace elements, serpentinite deposits, hyperaccumulation

To all intents and purposes, planet earth can be considered as a 'closed system'. In order to maintain a dynamic equilibrium, a multitude of interactions between various spheres of the earth take place. These interactions among the atmosphere, hydrosphere, lithosphere and the biosphere are extremely complex and the mechanisms of earth processes depend entirely on the reactions and interactions that constantly attempt to achieve thermodynamical stability. From among these myriads of interactions, those between the geosphere and the biosphere are of paramount importance in view of their implications on the sustenance of life on earth.

It is a fact that without soil there will be no plants and hence no food production. Soil is formed by the weathering of rocks and the physics and chemistry of the weathering of rocks therefore play a vitally important role in soil production. It is at the stage of soil-water-plant association that major geo-bio interactions take place. Controlled passage of vital chemical elements in their various forms of species through the "geo-bio" barriers notably from soil water, to plant cells is one of the most fascinating processes in nature.

Few people know that geoscientists have expanded their discipline by linking human and animal health with geology. To most people, geology is a subject concerning rocks and minerals and their distributions on Earth. The fundamental basis for this new link with human

Author's email: cbdissa@hotmail.com health, now established as the new discipline of Medical Geology is the unique interdependence of the different living and non-living components that make up the Earth. The basic building blocks of the earth - the rocks and minerals - must, therefore have a bearing on the health of the human and animal populations that live on these earthy materials (Dissanayake and Chandrajith, 2009).

\section{From rocks to plants: Serpentine flora}

The chemistry of the rocks of a particular terrain undoubtedly has an impact on the physiology of the flora of that particular terrain. Depending on the chemical composition of the rocks and minerals a particular terrain may have a unique geochemistry. Such terrains are broadly termed "geochemical provinces". Interestingly, in some parts of the world where mineralization is pronounced, there is an abundance of metals such as $\mathrm{Fe}, \mathrm{Cu}, \mathrm{N}, \mathrm{Cr}, \mathrm{V}, \mathrm{Co}, \mathrm{Zn}, \mathrm{Mo}$, Sn among others, in the soils originated by the weathering of the metal-rich rocks and minerals. The plants growing on these metalliferous soils which contain more than $1000 \mathrm{ppm}$ of metal are termed "hyperaccumulators".

In Sri Lanka, there are a few deposits of the rock serpentinite (a Mg-rich Ultrabasic rock containing metals such as $\mathrm{Fe}, \mathrm{Cr}, \mathrm{Ni}$ and $\mathrm{Zn}$ ). These cement coloured rocks are found mainly along a tectonic boundary between two major 
geological units termed the Highland Complex and the Vijayan Complex (Fig. 1)

Dissanayake and van Riel (1976) studied the serpentine deposit at Ginigalpelessa at Uda Walawe and noted that the weathered rock has a nickel content ranging from 1-4 ppm, worthy of further exploration. The deposit at Uda Walawe is itself about $2 \mathrm{~m}^{2}$ in area and has a unique flora. Other deposits notably those at Ussangoda and Indikolapelessa have also been studied. Fig. 2 shows a photograph of the Ussangoda and Ginigalpelessa terrains underlain by the rock serpentinite. Note the barren patches and the brown-red soil caused by high iron content.

\section{Vegetation}

Vegetation as a guide in exploration for nickel in ultramafic rocks is worthy of special mention. It is known that of all morphological changes produced on vegetation by the substrate, those found in serpentine floras are perhaps the most extreme. The distinction between the vegetation on serpentinites and the surrounding vegetation is so great that boundaries can be readily demarcated.

The use of vegetation as a guide to mineralization or geobotanical prospecting as it is termed has been the subject of much study. Indicator plants-those indicative of the type of mineral deposit upon which they grow - are being investigated thoroughly. While indicator plants for copper are well-represented, those for nickel are much less represented in literature. Early work by Brooks and his co-workers at Massey University, New Zealand has shown that there are a number of indicator plants for nickel growing on ultramafic substrates, which could be invaluable in exploration for nickel in such

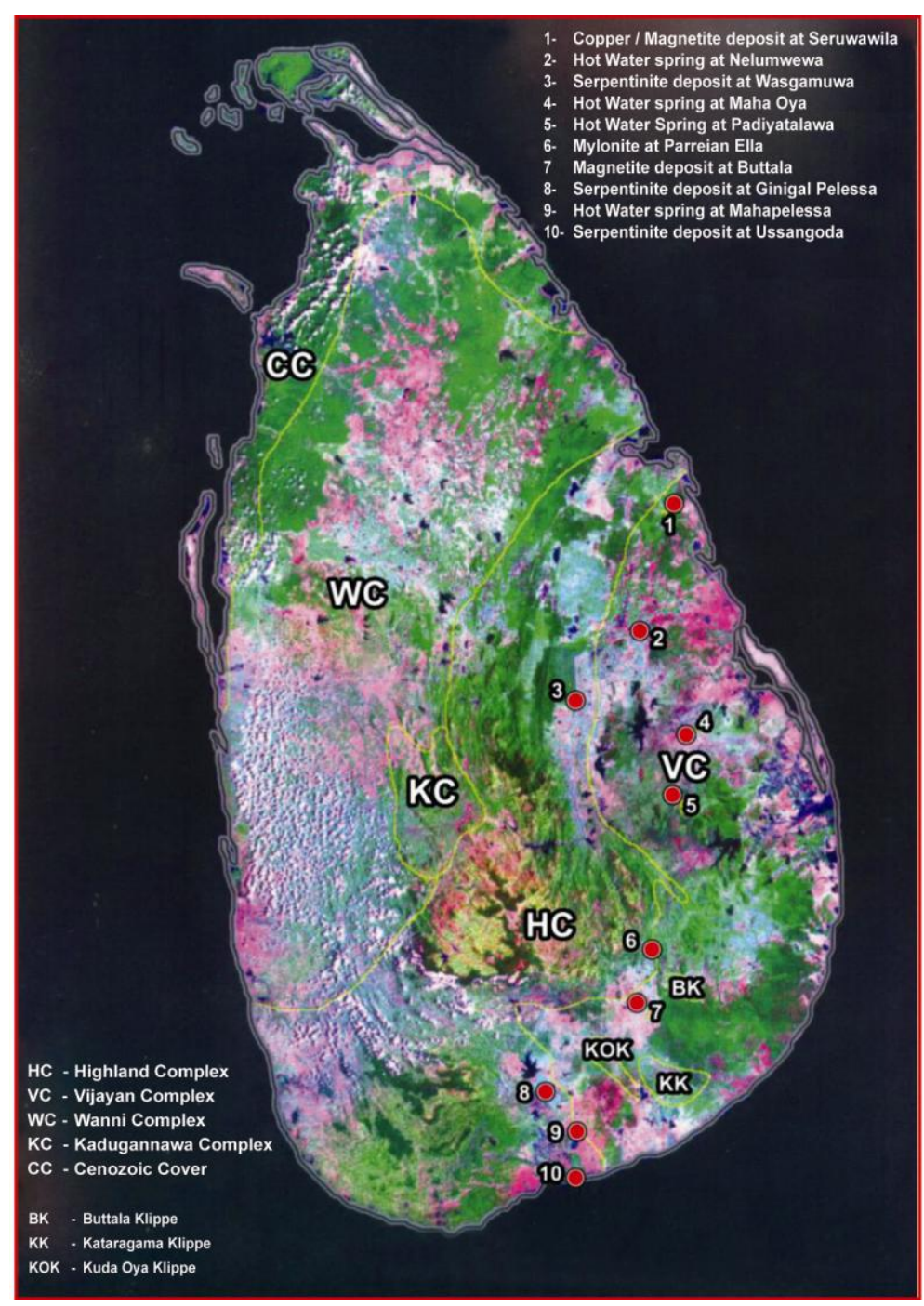

Figure 1. Map of Sri Lanka showing the serpentinite deposits. 
terrains. Brooks et al. (1977) have suggested that species containing more than $1000 \mu \mathrm{g} / \mathrm{g} \mathrm{Ni}$ (expressed on a dry-weight basis) be termed hyperaccumulators of nickel. Using this criterion, they have named 16 known hyperaccumulators of nickel. It is of interest to note that except for 4 species all are found in new Caledonia where the nickeliferous serpentine, garnierite, is known to occur in abundance. Among these is Sebertia acuminate (Sapotaceae), the latex of which is known to contain $25 \% \mathrm{Ni}$ on a dry-weight basis. This is easily the highest nickel concentration ever found in living material (Jaffre et al., 1976). Even though Sebertia acuminate is endemic to New Caledonia, there are various species of Hybanthus and Rhinorea (Violaceae), Alyssum (Cruciferae) and Psychotria (Rubiaceae) which the nickel prospector could use (Brooks et al., 1974). Brooks has in particular stressed the importance of the plant Rhinorea bengalensis as an indicator of nickel since it is found widely in humid tropical terrains particularly in South East Asia, and is known to contain as much as $1.7 \%$ $\mathrm{Ni}$ (dry-weight basis). The work of Brooks et al. (1977) has shown that analysis of herbarium specimens may be used to detect hyperaccumulators of nickel and that the data may be used to pin point ultramafic rocks throughout the world.

Rajakaruna and Bohm (2002) studied the soils and vegetation of four serpentine sites in Sri Lanka where the soil chemical and physical features were typical of ultramafic sequences. Their preliminary taxonomic survey identified 45 species of angiosperms, none of which are endemic to Sri Lanka or restricted to ultramafic soils. However, they suggested that populations of several taxa may represent distinct races or ecotypes specific to the substrate.

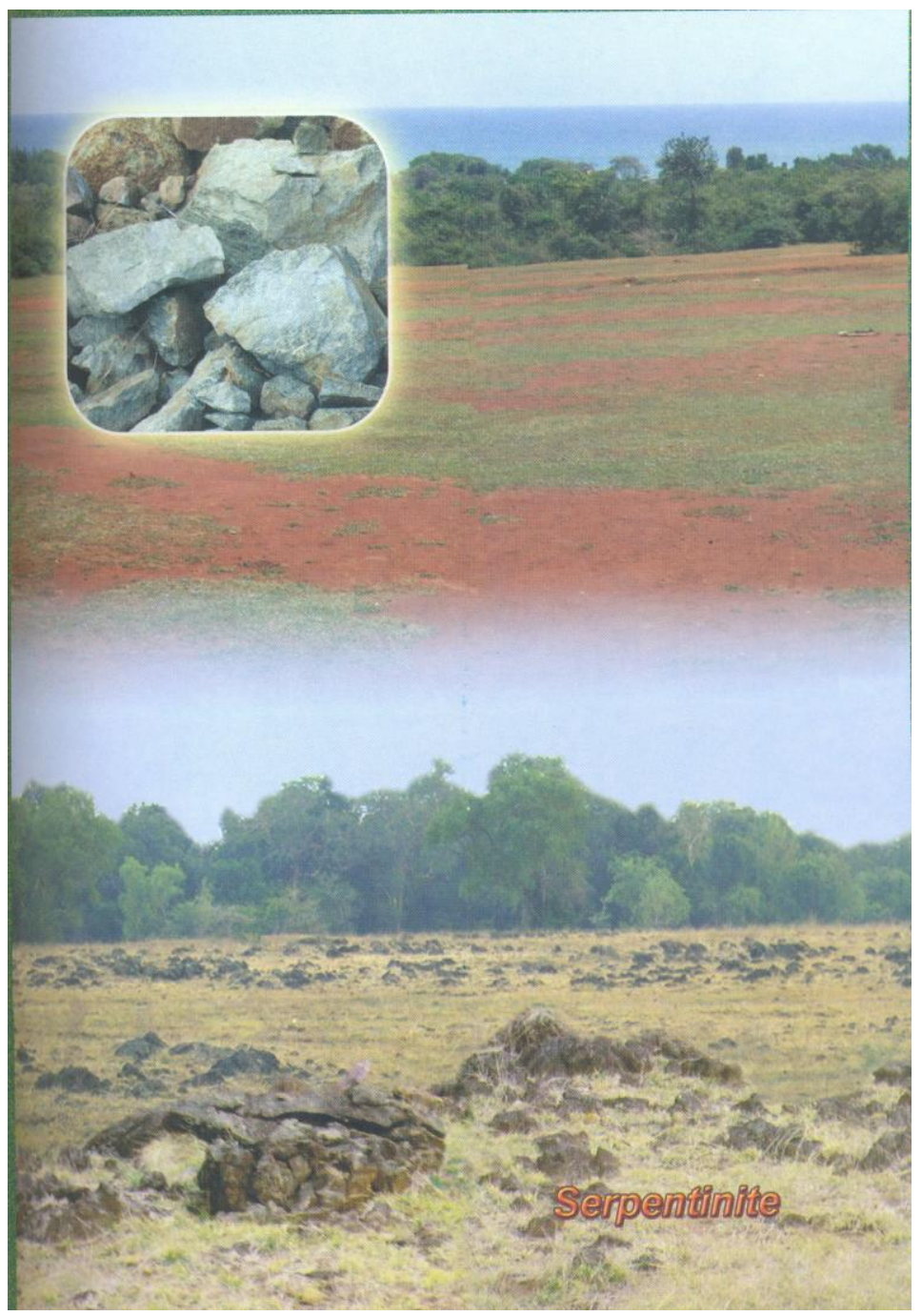

Figure 2. Serpentinite deposits at Ussangoda and Ginigalpelessa (Photo: Courtesy Geological Survey and Mines Bureau, 2011). 
Plant tissue concentrations of various elements were typical of species growing on ultramafic substrates. Evolvulus alsinoides (Convolvulaceae), Hybanthus enneaspermus (Violaceae) and Crotalaria biflora (Fabaceae) were shown to hyperaccumulate nickel $(>1000$ $\mu \mathrm{g} / \mathrm{g}$ dry tissue). An unusual finding was the discovery of five hyperaccumulators of copper: Geniosporum tenuiflorum (Lamiaceae), Clerodendrum infortunatum (Verbenaceae), Croton bonplandianus (Euphorbiacea), Waltheria indica (Sterculiaceae), and Tephrosia villosa (Fabaceae). Copper hyperaccumulation
(>1000 $\mu \mathrm{g} / \mathrm{g}$ dry tissue) in ultramafic substrates is a little known phenomenon and requires further study. Calotropis gigantean (Asclepiadaceae) accumulated sodium to levels often seen in halophytic plants. Sodium accumulation in plants growing on ultramafic substrates is also a rare phenomenon.

Table 1 shows the concentrations of elements in plant tissues. This work by Rajakaruna and Bohm (2002) is considered as an extremely valuable contribution to the study of serpentine flora in Sri Lanka.

Table 1. Plant tissue concentrations of various elements.

Measured concentrations are all within the detection limits of the ICP and are standardized using appropriate controls. All values are recorded in $\mathrm{ppm}(\mu \mathrm{g} / \mathrm{g}$ dry tissue). Values within parenthesis for eight selected species indicate values obtained from a separate analysis of tissue samples. The abbreviations used for the four sites are GGP=Ginigalpelassa, IP=Indikolapelassa, U=Ussangoda, Y=Yodhagannawa (Source: Rajakaruna and Bohm, 2002).

\begin{tabular}{|c|c|c|c|c|c|c|c|c|c|c|c|c|c|}
\hline & & & & & & & & & & & & & $\mathbf{C a} /$ \\
\hline Species & Site & Al & As & B & $\mathbf{B a}$ & $\mathbf{C a}$ & Cd & Co & $\mathrm{Cr}$ & $\mathbf{C u}$ & $\mathbf{F e}$ & $\mathbf{K}$ & Mg \\
\hline Aerva lanata & GGP & 194.5 & 2.9 & 13.9 & 29.9 & 976.3 & 0 & 12.7 & 12.5 & 171.2 & 1287.3 & 10119.02 & 0.1 \\
\hline Aristida setacea & GGP & 202.7 & 7.6 & 1.2 & 22.2 & 318 & 0 & 14.6 & 19.3 & 29.6 & 2994.3 & 10174.6 & 0.3 \\
\hline Asparagus zeylanicus & GGP & 154.7 & 0 & 21.6 & 3.3 & 1782.3 & 0.6 & 0.9 & 7 & 8.5 & 756.3 & 9391.7 & 0.2 \\
\hline Calotropic gigantean & GGP & 119.9 & 0 & 45.2 & 9 & 1910.2 & 0 & 0.84 & 7.05 & 582.5 & 308.1 & 8204.9 & 0.1 \\
\hline Canthium puberulum & GGP & 24.4 & 2.7 & 11.8 & 3.7 & 1515.5 & 0.38 & 0.12 & 3.7 & 24.9 & 105.1 & 5549.6 & 0.4 \\
\hline Cantium sp. & GGP & 335.1 & 2.7 & 23 & 32.3 & 2141.2 & 0 & 5.1 & 15.6 & 211.2 & 2121.5 & 4651.9 & 0.2 \\
\hline Carissa spinarum & GGP & 203.5 & 0 & 24.9 & 43.6 & 7062.6 & 0.4 & 1.6 & 7.3 & 701.6 & 721.2 & 5399.6 & 0.5 \\
\hline Clerodendrum infortunatum & GGP & 165.6 & 0.2 & 19.7 & 6.5 & 3371.5 & 2 & 0.6 & 8.4 & $\begin{array}{l}2278.2 \\
(2138)\end{array}$ & 434.8 & 9989.6 & 0.4 \\
\hline Croton bonplandianus & GGP & 189 & 0.2 & 23.9 & 18.9 & 2283.9 & 0.9 & 1.6 & 11.3 & $\begin{array}{l}2162.7 \\
(2249)\end{array}$ & 775.3 & 12806.8 & 0.2 \\
\hline Croton hirtus & GGP & 348.1 & 3.2 & 16.9 & 36.9 & 1655.4 & 0 & 4.4 & 39.8 & 7.5 & 1239.3 & 7203.3 & 0.1 \\
\hline Eupatorium odoratum & GGP & 252.7 & 0 & 32 & 11.7 & 1654.1 & 7.4 & 3.1 & 12.3 & 89.1 & 1347.9 & 14393.1 & 0.2 \\
\hline Euphorbia rubicunda & GGP & 274.2 & 0.8 & 20.5 & 47.4 & 1538.1 & 0.51 & 1.3 & 9.6 & 109.8 & 755.2 & 6828.1 & 0.3 \\
\hline Leucas zeylanica & GGP & 338.5 & 1.7 & 18.4 & 50.9 & 1143.2 & 0 & 9.4 & 28.2 & 43 & 1146.7 & 12725.2 & 0.1 \\
\hline Morinda tinctoria & GGP & 226.4 & 0.7 & 27.2 & 9 & 3542.5 & 0.14 & 0.7 & 4.38 & 2.7 & 352.7 & 4795 & 0.3 \\
\hline Ocimum sanctum & GGP & 365.1 & 1.9 & 12.73 & 50.7 & 10326.2 & 0.05 & 1.9 & 12.11 & 266.13 & 946.95 & 10404.1 & 1.8 \\
\hline Phoenix farinifera & GGP & 208.7 & 1.8 & 4.9 & 1.2 & 547.6 & 0 & 0.04 & 1.8 & 131.8 & 183.9 & 3670.9 & 0.2 \\
\hline Phyllanthus sp. & GGP & 313.4 & 0.2 & 18.4 & 11.3 & 3198.4 & 0 & 2.4 & 11.3 & 820.5 & 952.8 & 2875 & 0.4 \\
\hline Cymbopogan flexuosus & GGP & 66.2 & 0.8 & 2.5 & 1.7 & 222.6 & 0 & 0.3 & 26.3 & 7.6 & 280.8 & 2573.4 & 0.1 \\
\hline Cymbopogan flexuosus & IP & 62.1 & 0 & 2.6 & 2.8 & 812.8 & 0 & 0.4 & 17.6 & 8.6 & 278.2 & 5882.4 & 0.2 \\
\hline Waltheria indica & GGP & 238.5 & 0 & 20.5 & 13.7 & 2570.9 & 0.65 & 1.33 & 8.1 & $\begin{array}{l}1504.3 \\
(1563)\end{array}$ & 843.4 & 4641.9 & 0.3 \\
\hline
\end{tabular}




\begin{tabular}{|c|c|c|c|c|c|c|c|c|c|c|c|c|c|}
\hline Species & Site & Mg & Mn & Mo & $\mathbf{N a}$ & $\mathrm{K} / \mathrm{Na}$ & $\mathrm{Ni}$ & $\mathbf{P}$ & $\mathbf{P b}$ & $\mathrm{Se}$ & $\mathrm{Si}$ & $\mathrm{Sr}$ & $\mathbf{Z n}$ \\
\hline Aerva lanata & GGP & 8371.3 & 124.5 & 0 & 206.7 & 49 & 156.5 & 1113.1 & 8.3 & 0 & 140.9 & 13.1 & 46.8 \\
\hline Aristida setacea & GGP & 1090.7 & 207.4 & 0 & 494.6 & 21 & 439.1 & 838.2 & 7.9 & 0 & 195.1 & 12.0 & 58.1 \\
\hline Asparagus zeylanicus & GGP & 7941.4 & 28.8 & 0.1 & 1270 & 7 & 28.8 & 1110.6 & 2.5 & 0 & 76.7 & 9.5 & 20.7 \\
\hline Calotropic gigantean & GGP & 21125.6 & 66.03 & 0.4 & 12017 & 0.7 & 97.4 & 2715.2 & 20.4 & 0 & 520.7 & 21.7 & 249.6 \\
\hline Canthium puberulum & GGP & 3609.5 & 14.8 & 0 & 96.1 & 58 & 20.3 & 1237.2 & 0.92 & 0.1 & 27.5 & 13.8 & 19.4 \\
\hline Cantium sp. & GGP & 10789.1 & 60.3 & 0 & 396.8 & 12 & 104.4 & 868.3 & 2.3 & 0 & 245.9 & 19 & 21.5 \\
\hline Carissa spinarum & GGP & 14721.1 & 44.9 & 0.9 & 1069.1 & 5 & 66.8 & 1411.5 & 8.6 & 0 & 440.5 & 36.8 & 96.2 \\
\hline Clerodendrum infortunatum & GGP & 8314.2 & 34.8 & 0.6 & 176.9 & 59 & 45.6 & 1916.9 & 53.9 & 0 & 54.2 & 16.2 & 303.3 \\
\hline Croton bonplandianus & GGP & 12816.1 & 82.2 & 0.3 & 394.9 & 32 & 52.9 & 3969.6 & 71.5 & 0 & 81.3 & 20.5 & 254.7 \\
\hline Croton hirtus & GGP & 12014.6 & 105.26 & 0.13 & 838.1 & 9 & 116.3 & 1661.3 & 4.4 & 0 & 269.1 & 23 & 28.5 \\
\hline Eupatorium odoratum & GGP & 11317 & 38.96 & 0.63 & 163.3 & 75 & 83.7 & 1641.1 & 3.5 & 0 & 156.5 & 8.8 & 76.4 \\
\hline Euphorbia rubicunda & GGP & 6164.5 & 30.5 & 0 & 316.3 & 22 & 36.6 & 2330.2 & 2.7 & 0 & 81.6 & 29.2 & 46.2 \\
\hline Leucas zeylanica & GGP & 9789.5 & 94.01 & 0 & 257.4 & 50 & 142.2 & 1877.6 & 8.6 & 0 & 152 & 16.2 & 44.1 \\
\hline Morinda tinctoria & GGP & 11122.7 & 65.2 & 0.21 & 536.8 & 9 & 29.8 & 1286.5 & 2.6 & 0 & 366.6 & 16.0 & 33.71 \\
\hline Ocimum sanctum & GGP & 5705.5 & 36.1 & 0.5 & 634.2 & 16 & 28.82 & 2598.1 & 8.8 & 0 & 67.8 & 42.1 & 98.2 \\
\hline Phoenix farinifera & GGP & 3446.8 & 45.2 & 0 & 1343.7 & 3 & 4.4 & 903.4 & 3.5 & 1.4 & 60.8 & 0.75 & 30.7 \\
\hline Phyllanthus sp. & GGP & 7410.5 & 73.7 & 0 & 172.5 & 17 & 72 & 1131.3 & 21.5 & 0 & 158.3 & 20.7 & 222.8 \\
\hline Cymbopogan flexuosus & GGP & 2139 & 15.9 & 0.2 & 208.7 & 12 & 21.3 & 974.8 & 4.4 & 0 & 126.2 & 1.6 & 23.5 \\
\hline Cymbopogan flexuosus & IP & 3823.7 & 31.2 & 0.6 & 299.5 & 20 & 19.1 & 982.2 & 0 & 0 & 94.7 & 7.6 & 30.1 \\
\hline Waltheria indica & GGP & 10014.1 & 59.35 & 0.7 & 71.4 & 65 & 60.3 & 1882.3 & 27.3 & 0 & 142.1 & 20.8 & 301.7 \\
\hline
\end{tabular}

\section{Rock-soil-water-health interactions}

Rocks which contain a large number of minerals with varying compositions and which are found in the human habitats play a very significant role in the distribution of chemical elements in our environment. It has generally been the practice to classify these elements as essential, non-essential and toxic based on their impacts on human health. Elements such as $\mathrm{K}, \mathrm{P}$, $\mathrm{N}, \mathrm{Ca}, \mathrm{Mg}, \mathrm{Fe}, \mathrm{Zn}$, Se and I among several others are considered essential for good health, while elements such as $\mathrm{Pb}, \mathrm{Cd}, \mathrm{Hg}, \mathrm{U}$, As etc. have a detrimental impact on the human body and are therefore classed as toxic. However, at the very outset, it should be mentioned that even for essential elements, there is an optimum dosage and beyond this level, harmful effects will emerge. Diseases caused by excess Fe, P, $\mathrm{Ca}$ and $\mathrm{K}$ are well known in human physiology.

The weathering of rocks under natural conditions of the environment aided by soil acids and water, marks the beginning of the geochemical cycle on the surface of the Earth and the chemical elements concerned depending on their basic chemistry, get dispersed in air, soil, water and plants. Some elements termed "Geochemically Mobile" (e.g. Na, K) disperse very fast while others (e.g. $\mathrm{Pb}$ ) tend to be sluggish or slow in their dispersion. It should however, be noted that the geochemical mobility depends markedly on the chemistry of the earthy materials with which the element concerned is associated, $\mathrm{pH}$ being an important parameter. Based on the chemistry of the mother rocks 
therefore, terrains will have a particular chemical composition in their soils and water and these, naturally, will have an impact on the humans and animals that live intimately associated with these earthy materials (Fig. 3). One could thus clearly infer that for example those living in the Jaffna Peninsula which is underlain by sedimentary carbonate rocks of $\mathrm{Ca}$ and $\mathrm{Mg}$ will have their groundwater rich in these elements. Hence, a higher body burden of $\mathrm{Ca}$ and $\mathrm{Mg}$. Terrain geochemistry is therefore of primary importance in epidemiological studies. Excesses and deficiencies of essential trace elements will therefore be markedly influenced by terrain geochemistry, particularly among the rural people who obtain their food and water directly from the immediate physical environment of the terrain.

It is well known that water is unique in its ability to dissolve a whole range of chemical elements and their compounds. The chemistry of the surface water, deep well water, tank water etc. are therefore of vital importance in the general health of the rural population. Likewise the chemistry of the irrigation water as supplied by the Mahaweli mega scheme to the Dry Zone of Sri Lanka is of equal importance in human health concerns. High total dissolved ion content, halogens such as fluoride and chloride, abundance of $\mathrm{Ca}$ and $\mathrm{Mg}$, total hardness etc. may play an important role in the aetiology of many diseases, notably in the Dry Zone.

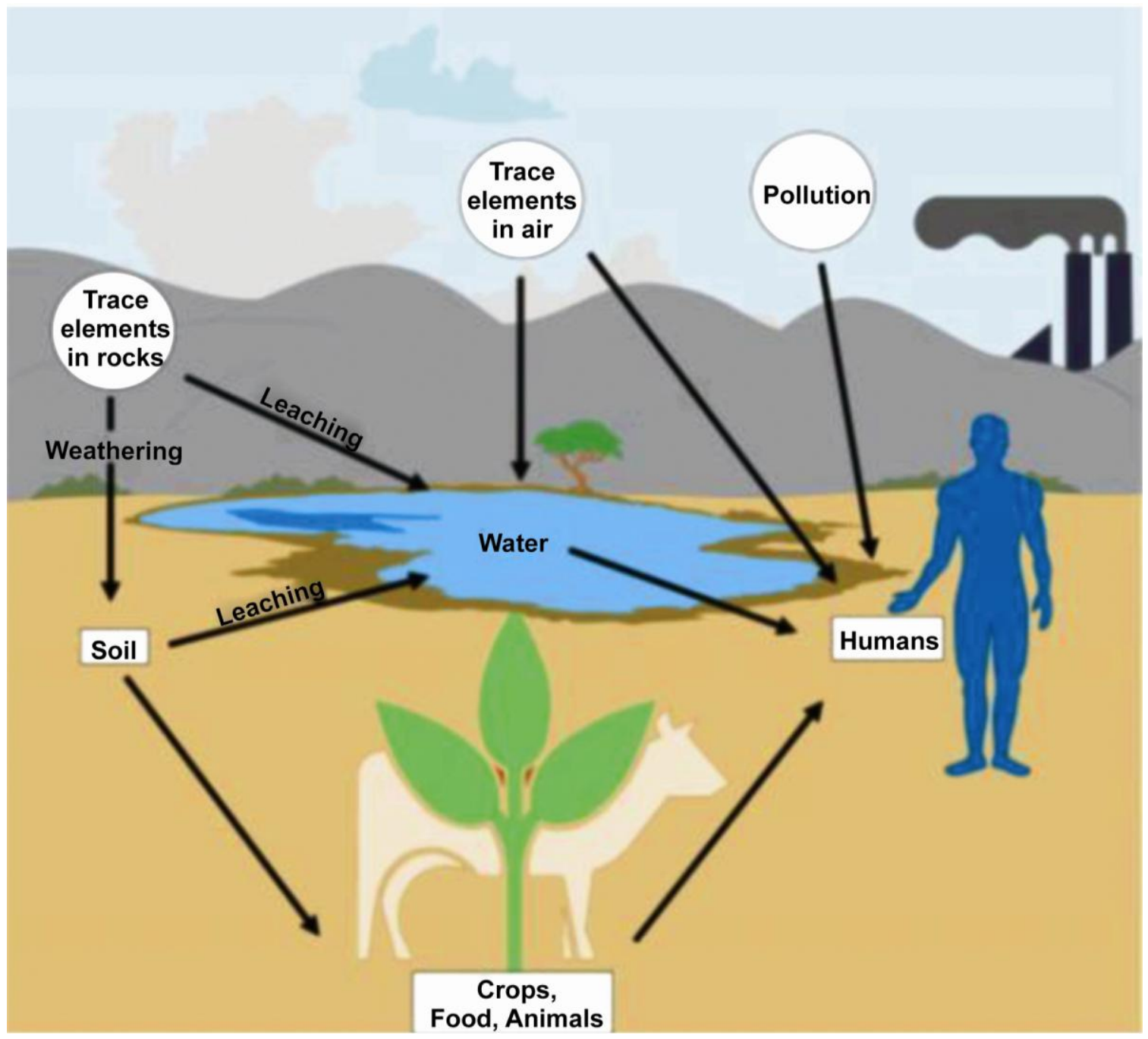

Figure 3. Humans as a part of the Geochemical cycle. 


\section{Bioavailability and bioaccumulation}

The mere presence of an element, whether toxic or essential, in the environment does not by itself constitute an impending disaster. It is the ease of entry of this material into the human body which is of greater importance. The entry of fluoride from the rocks, minerals and water into the human body is greatly facilitated by the similarity of the chemistry of the hydroxyl groups and the fluoride ions. This has resulted in the markedly high levels of fluoride in the groundwater of the North Central regions resulting in dental fluorosis and skeletal fluorosis (Fig. 4). In the wet zone on the other hand, the fluoride ions are flushed away by high rainfall resulting in a much lower preponderance of these ions in the water, hence the lower impact on the human body. The geo-bio interactions thus need to be studied in depth in such correlative studies. The entry of the toxic element $\mathrm{Cd}$ into the human body was of major concern in Japan when the "Itai-Itai" disease was first identified. Here too, the understanding of the "geo-bio interactions" and the geochemical pathways paved the way for the cause to be discovered.

In a very general sense, bioaccumulation could be defined as "the process by which organisms absorb chemicals or elements directly from the environment". It should however be noted that the term "bioaccumulation" has to be specified by quantitative data, comparing concentrations of a compartment in relation to another (e.g. plant vs. soil parts, adsorbed amount vs. dissolved amount) (Streit, 1992). The selective concentration of elements is inherent in any life process and the process of bioaccumulation therefore leads to indications of pollution of the environment. The chemistry of the elements and the biochemical structure of the biological species are the main factors that influence the bioaccumulation process.

The passage of metal ions into the plants through the soil solution and root cells depends on a number of factors such as redox potential, $\mathrm{pH}$, interaction with ligands and properties of soil matrix such as cation exchange capacity. The metal speciation in soil solution and on soil surfaces and metal uptake by the root is illustrated in Fig. 5. The root cell membranes are highly selective to trace elements. The phospholipid based membranes are highly impermeable to ions or (large) polar molecules, whereas non-polar molecules (such as $\mathrm{O}_{2}$ ) pass rapidly. The electric potentials between membrane separated compartments, known to correlate with $\mathrm{pH}$ gradients play an important role in soil solution-plant pathways (Streit and
Stumm, 1993). The mechanism of passage of elements through cell membranes is complex and very little is still known about the actual selective process.



Figure 4. Cases of dental fluorosis and skeletal fluorosis.

The term bioavailability has been defined in a number of ways. In a very general way, one could define bioavailability as "the extent to which a substance can be absorbed by a living organism and can cause an adverse physiological or toxicological response" (NEFESC, 2000). For environmental risk assessments which involve soil and sediment, the above definition implicitly includes the medium in which it occurs to become available for absorption. 
Other definitions of bioavailability depend on the scientific discipline which requires such a definition. For example:

i. Environmental bioavailability: Physiologically driven uptake process (Peijnenburg et al., 1997) ii. Toxicological bioavailability: The fraction of the total available dose absorbed by an organism which is distributed by the systemic circulation and ultimately presented to the receptor or sites of toxic action (Landrum and Hayton, 1992) iii. Bioremediation bioavailability: The extent to which a contaminant is available for biological conversion (Juhasz et al., 2003). Other terms such as pharmacological bioavailability, phytobioavailability and bioaccessibility have also been used (Landrum and Hayton, 1992).

Carbonate rocks, water hardness and cardiovascular diseases

One of the most intriguing, yet, not well defined geochemistry-health correlations is the incidence of cardiovascular diseases (CVD) in connection with water hardness of a particular area (Crawford et al., 1977; Comstock, 1979; Bernadi et al., 1995)

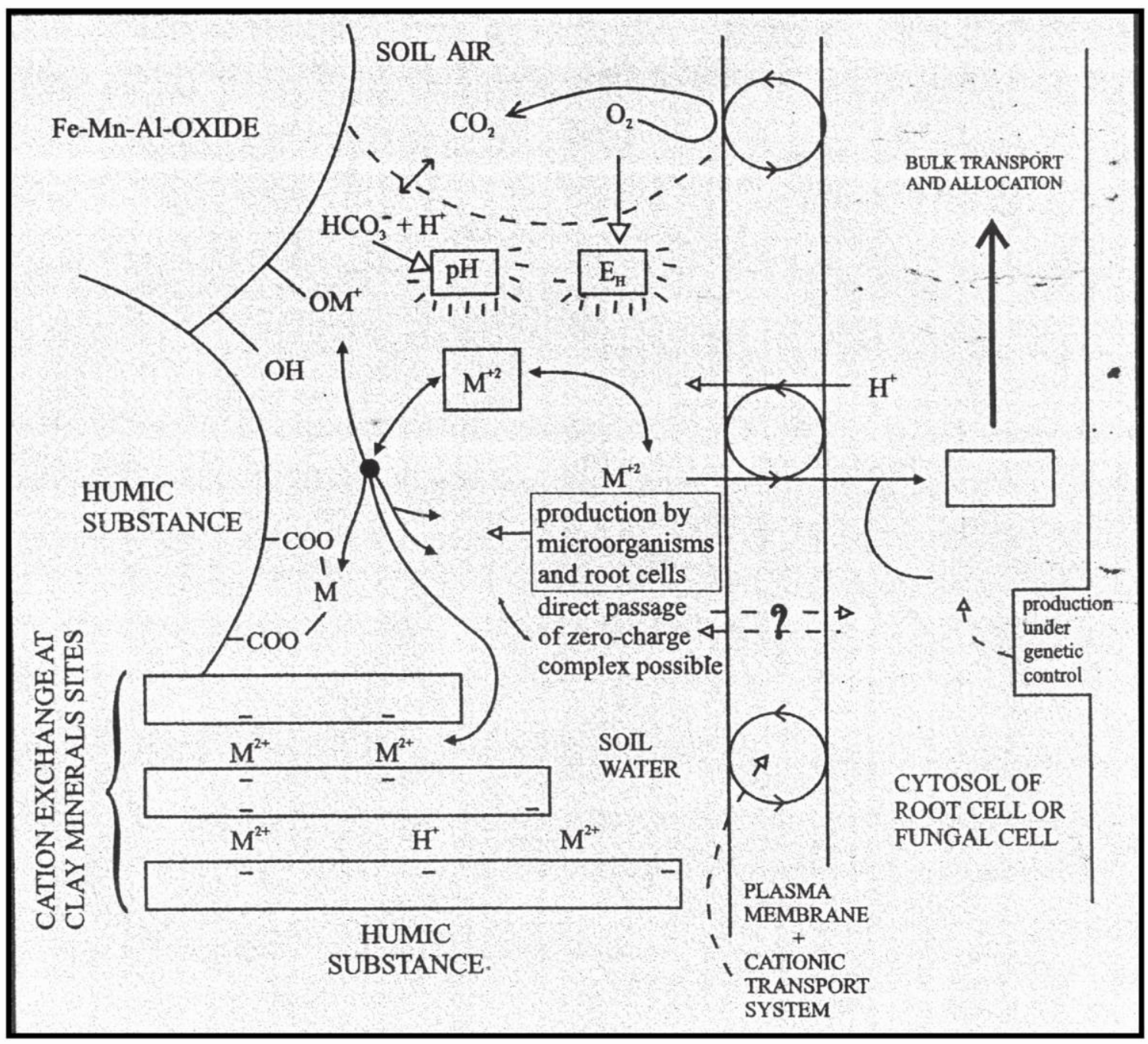

Figure 5. Highly schematic diagram to show metal speciation in soil solution and on soil surfaces and root metal ion uptake, assuming a divalent metal cation $\left(\mathrm{M}^{2+}\right)$ and a monovalent soluble external ligand. The uptake rate into the cell is determined (in a given individual) by the number of metal ions bound to receptor sites on membrane transport molecules, e.g. metal ion ATPases. At equilibrium the amount of metal bound to these sites and therefore the transport rate, would be directly related to the soil metal ion concentration (Source: Streit and Stumm, 1993). 
In certain areas, as in some parts of Sri Lanka where carbonate-rich rocks are abundant, the ground water tends to be rich in $\mathrm{Ca}, \mathrm{Mg}$ and carbonates resulting in hard water.

Water hardness has been defined in the literature in a variety of ways with multiple units being used to express it, such as German, French and English degrees; equivalent $\mathrm{CaCO}_{3}$ or $\mathrm{CaO}$ in $\mathrm{mg} / \mathrm{l}$. Even though initially water hardness was rather vaguely defined as a measure of the capacity of water to precipitate soap, it is now generally accepted that hardness is defined as the concentrations of calcium and magnesium ions or as $\mathrm{CaCO}_{3}$ equivalent in $\mathrm{mg} / \mathrm{l}$. General guidelines for classification of water are given below:

\begin{tabular}{ll}
\hline $\mathbf{C a C O}_{\mathbf{3}} \mathbf{~ m g / l}$ & Water hardness \\
\hline $0-60$ & Soft \\
$61-120$ & Moderately hard \\
$121-180$ & Hard \\
$>180$ & Very hard \\
\hline
\end{tabular}

Most natural water supplies contain at least some hardness due to dissolved calcium and magnesium bearing carbonates and silicates. Elements such as iron may contribute to the hardness of water, but in natural water, they are generally present in low quantities. The total hardness of water may range from trace amounts to milligrams per litre.

\section{Causation and Correlation}

These two terms are very frequently used in both medical geology and epidemiology. The term 'association' is also used in conjunction with correlation if two variables appear to be related by a mathematical relationship, indicating that a change of one appears to be related to the change in the other. Causation is used in epidemiology when the following conditions are satisfied;

(a) A dose-response relationship exists between the condition and the disease.

(b) The prevalence or the incidence of the disease is reduced when the condition under study is removed.

(c) The condition precedes the disease.

(d) A cause and effect relationship is physiologically plausible.

It is however, most important to note that a correlation does not always imply a causal relationship even though a correlation is necessary for a causal relationship. A correlation can be of two types, namely a negative correlation and a positive correlation. In the former, the magnitude of one variable moves in the opposite direction to the other associated variable. Here, the correlation coefficient is negative. If the relationship is definitely causal, then the higher levels of the risk factor are protective against the outcome. In the case of a positive correlation, the two variables change in the same direction and the correlation coefficient is positive. Here, higher the levels of the risk factor, higher are the outcome. Correlation however measures only linear association. The fact that a statistical correlation alone does not prove causation may be due to the presence of other contributing or confounding factors. This provides misleading evidence and lead researchers to find an association for the wrong reason.

One of the earliest studies on the relationship between water hardness and the incidence of vascular diseases was by a Japanese chemist Kobayashi (1957). He showed on epidemiological grounds higher mortality rates from cardiovascular diseases (strokes) in the areas of Japanese rivers with softer water compared to areas with hard water used for drinking purposes. Kožíšek (2003) has summarized the beginnings of research that led to the health significance of water hardness. He mentions that among the best known studies is that by Schroeder (1960) who showed a correlation between mortality from CVD in males (ages 45-64 years) and water hardness in 163 largest cities of the USA and who summarized his results under the caption "soft water, hard arteries".

Within the first two decades of research into water hardness in association with cardiovascular diseases, more than 100 papers had been published (Hewitt and Neri, 1980). In several countries and areas, a negative correlation has been observed between water hardness and death rate due to heart diseases (Masironi, 1979; Pocock et al., 1980; Teitge, 1990). Even though a definite causal effect still cannot be ascribed to this geochemical correlation, the effect of trace elements in drinking water on heart diseases has caused great interest among medical geologists. It is of particular interest to note that such a negative association between water hardness and cardiovascular pathology is evident in both industrialized and developing countries in the tropics (Fig. 6). 


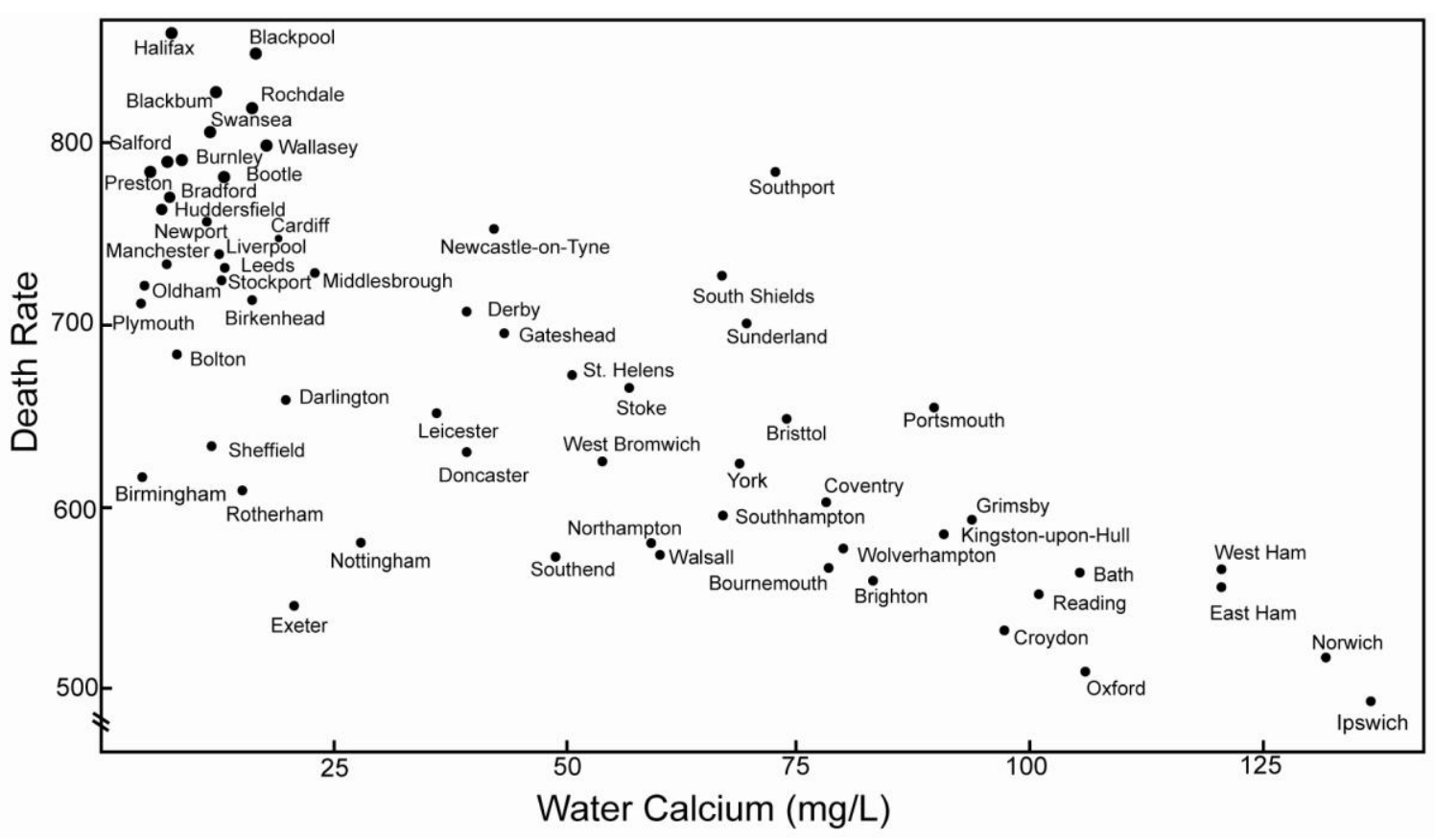

Figure 6. Water calcium in some areas in England and Wales in relation to cardiovascular death rate (per 100,000 men), ages 45-64 years during 1958-1964 (Sources: Gardner, 1973; Keil, 1979).

It should, however, be mentioned that not all studies confirm such a relationship. Miyake and Iki (2004) for example, in a recent study, observed that there is a lack of association between water hardness and coronary heart disease (CHD) mortality in Japan. These authors observed that in males, after adjustment for age, an inverse dose-response relationship between water hardness and mortality from CHD was significant $(\mathrm{p}=0.004)$. However, the relationship virtually disappeared after further adjusting for socioeconomic status and health care status. In females they found no association between water hardness and coronary mortality. Nonetheless, a large number of studies in many countries suggest such a correlation and geochemically it is worthy of serious study.

There are several other "geology-health" interactions such as fluoride and chronic kidney disease (Chandrajith et al., 2011) iodine geochemistry and endemic goitre (Dissanayake, et al., 1998) selenium geochemistry and human physiology (Fordyce et al., 2000). These geobio interactions therefore deal with boundary conditions and provide truly fascinating scientific information leading to a better understanding of how earth processes work.

\section{REFERENCES}

Bernadi, D., Dini, F.L., Azzrelli, A., Giaconi, A., Volterrani, C. and Lunardi, M. (1995). Sudden cardiac death rate in an area characterized by high incidence of coronary artery disease and low hardness of drinking water. Angiology 46: 145-149.

Brooks, R.R., Lee, J and Jaffre, T. (1974). Some New Zealand and New Caledonian plant accumulators of nickel. J. Ecol. 62: 493-499.

Brooks, R.R., Lee, J., Reevers, R.D. and Jaffre, T. (1977). Indicator plants for nickeliferous rocks. J.Geochem. Expl 7:49-57.

Chandrajith, R., Dissanayake, C.B., Ariyarathna, T., Herath, H.M.J.M.K. and Padmasiri, J.P. (2011). Dose-dependent $\mathrm{Na}$ and $\mathrm{Ca}$ in fluoriderich drinking water - another major cause of chronic renal failure in tropical arid regions. Science of the total environment 409: 671-675.

Comstock, G.W. (1979). Water hardness and cardiovascular diseases. American Journal of Epidemiology 110: 375-400. 
Crawford, M.D., Clayton, D.G., Stanley, F. and Shaper, A.G. (1977). An epidemiological study of sudden death in hard and soft water areas. $J$. Chron. Diseases 30: 69-80.

Dissanayake, C.B. and Chandrajith, R. (2009) Introduction to Medical Geology, Springer Verlag (Germany) $297 \mathrm{Pp}$.

Dissanayake, C.B., Chandrajith, R. and Tobschall, H.J. (1998). Geochemistry of endemic goiter, Sri Lanka. Applied Geochemistry, Suppl. issue 2: 211-213.

Dissanayake, C.B. and van Riel, B.J. (1976). A recently discovered nickeliferous serpentinite from Uda Walawe, Sri lanka. Geologie en Mijnbouw. 57:91-92.

Fordyce, F., Johnson, C.C., Navaratne, U.R.B., Appleton, J.D. and Dissanayake, C.B. (2000). Selenium and iodine in soil rice and drinking water in relation to endemic goiter in Sri Lanka. Sci. of Total Environ. 263: 127-141.

Gardner, M. (1973). Soft water and heart disease? In: J. Lenihan and W.W. Fletcher (Eds), Health and the Environment, Blackie, Glasgow \& London. $121 \mathrm{Pp}$.

Hewitt, D. and Neri, L.C. (1980). Development of the "water story" some recent Canadian studies. J. Environ. Pathol. Toxicol. 4(2-3): 5163.

Jaffre, T., Brooks, R.R., Lee, J. and Reeves, R.D (1976). Sebertia acuminata. A hyperaccumulator of nickel from New Caledonia. Science 193:579580 .

Juhasz, A., Smith, E. and Naidu, R. (2003). Estimation of human availability of arsenic in contaminated soils. In: A. Langley, M. Gilbey and B. Kennedy (Eds), Proc $5^{\text {th }}$ National Workshop on the assessment of site contamination. National Environmental Protection Council Service Corporation. Pp. 183-194.

Keil, U. (1979). Hardness of drinking water (content of bulk and trace elements) and cardiovascular diseases (in German). Geographische Zeitschrift Sonderdruck. Geomedizin in Forschung und Lehre. Franz Steiner Verlag GmbH, Wiesbaden. Pp 59-76.

Kobayashi, J. (1957). On geographical relationship between the chemical nature of river water and death rate from apoplexy. Berichte des Ohara Instituts für landwirtschaftliche Biologie 11, Okayama University 14: 12-21.

Kožíšek, F. (2003). Health significance of drinking water calcium and magnesium. National Institute of Public Health Czech Republic (http://wwwszucz/chzp/voda/pdf/ hardness.pdf).

Landrum, P.F. and Hayton, W.L. (1992). Synopsis of discussion session on the kinetics behind environmental bioavailability. In: J.L. Hamelink, P.F. Landrum, H.L. Bergman and W.H. Benson (Eds), Bioavailability Physical Chemical and biological interactions. Proc. of a workshop held in Pellston Michigan, Lewis Publishers.

Masironi, R. (1979). Geochemistry and cardiovascular diseases. Phil-Trans. Roy. Soc. London Series B 288: 193-201.

Miyake, Y. and Iki, M. (2004). Lack of association between water hardness and coronary heart disease mortality in Japan. Int. J. Cardiol. 96: 25-28.

NEFESC (2000). Guide for incorporating bioavailability adjustments into human health and ecological risk assessments at US Navy and Marine corps facilities Part 1: Metals bioavailability Naval Facilities, NEFESC Engineering Command Washington DC, UG 2041-Env, pp. 56.

Peijnenburg, W.J.G.M., Posthuma, L., Eijsackers, H.J.P. and Allen, H.E. (1997). A conceptual framework for implementation of bioavailability of metals for environmental management purposes. Ecotoxicology and Environmental Safety 37: 163-172.

Pocock, S.J., Shaper, A.G., Cook, D.G., Packham, R.F., Lacey, R.F., Powell, P. and Russell, P.F. (1980). British regional heart study: geographic variations in cardiovascular mortality and the role of water quality. Br. Med. J. 250: 1243-1249.

Rajakaruna, N. and Bohm, B.A. (2002). Serpentine and its vegetation: A preliminary study from Sri Lanka. Journal of Applied Botany 76: $20-28$

Schroeder, H.A. (1960). Relation between mortality from cardiovascular disease and treated water supplies: variations in states and 
163 largest municipalities of the United States. J. American Med. Assoc. 172: 1902-1908.

Streit, B. (1992). Bioaccumulation processes in ecosystems. Cellular and Molecular Life Sciences 48: 955-970.

Streit, B. and Stumm, W. (1993). Chemical properties of metal and the process of bioaccumulation in terrestrial plants. In: B. Markert (Ed) Plants as Biomonitors for Heavy Metal Pollution of the Terrestrial Environment. Verlag Chemie, Weinheim, New York.
Teitge, J.E. (1990). Incidence in myocardial infarct and mineral content of the drinking water. Z. Gesmte. Inn. Med. 45: 478-485. 